\author{
Marek Studenski* \\ Bielsko-Biała
}

\title{
Resocjalizacja w środowisku otwartym mit czy rzeczywistość? \\ Toruń, 22 listopada 2012 roku
}

Wśród pytań stawianych na gruncie pedagogicznych dociekań są takie, które mają znaczenie dla samej tylko teorii wychowawczej, a z praktyką związane są jedynie pośrednio. Należy do nich na przykład szeroko pojęta problematyka różnego rodzaju założeń, z których wynikają koncepcje wychowawcze. Są także i takie pytania, które związane są bezpośrednio z praktyka, a odpowiedź na nie rzutuje na podejmowane przez wychowawców działania. Do takich problemów o charakterze praktycznym, których rozwiązanie kształtuje rzeczywistość wychowawczą, należy pytanie postawione przez Katedrę Teorii Opieki i Wychowania Wydziału Nauk Pedagogicznych Uniwersytetu Mikołaja Kopernika w Toruniu - organizatora Ogólnopolskiej Konferencji Naukowej, jaka odbyła się w Toruniu w dniu 22 listopada 2012 r. Uczestnicy konferencji podjęli refleksję skupioną wokół problemu, który został sformułowany w postaci pytania: Resocjalizacja w środowisku otwartym - mit czy rzeczywistość?

O godz. 10.00 rozpoczęła się część plenarna konferencji. Zebranych gości powitała prorektor Uniwersytetu Mikołaja Kopernika w Toruniu, dr hab. Beata Przyborowska, prof. UMK, która wyraziła radość z faktu zorganizowania spotkania i zwróciła uwagę na wagę postulowanej przez wyznaczony temat problematyki. Następnie głos zabrał dziekan Wydziału Nauk Pedagogicznych Uniwersytetu Mikołaja Kopernika w Toruniu, dr hab. Piotr Pe-

* Ks. dr Marek Studenski jest wykładowcą w Instytucie Teologicznym im. Św. Jana Kantego w Bielsku-Białej. 
trykowski, prof. UMK, który wychodząc od biblijnego pytania - „Adamie, gdzie jesteś?" i stawiając retoryczny problem, czy jest ono świadectwem „niewiedzy Przedwiecznego”, czy może wynika z innych źródeł, zainspirował uczestników konferencji do poszukiwania odpowiedzi na pytanie o środowisko, w którym osoby będące w szczególnych sytuacjach życiowych mogłyby znaleźć pomoc i wsparcie. Moderatorem części plenarnej był ks. dr hab. Czesław Kustra, prof. UMK, gospodarz konferencji, który dokonał wprowadzenia słuchaczy w jej problematykę.

Pierwszy spośród zaproszonych prelegentów - prof. zw. dr hab. Andrzej Bałandynowicz z Uniwersytetu Przyrodniczo-Humanistycznego w Siedlcach w referacie: Katalaktyczno-inkluzyjna reintegracja społeczna skazanych, zwrócił uwagę na potrzebę gruntownego przewartościowania myślenia o resocjalizacji. Według Prelegenta na jakość życia człowieka składaja się: bogactwo przeżyć, poziom świadomości (rozumienie świata), poziom aktywności (życie czynne), twórczość (tworzenie nowych szlachetnych idei) oraz współuczestnictwo w życiu społecznym, obejmujące podejmowanie wspólnych zadań, włączanie własnej działalności do dorobku ogólnego. Rozwój człowieka powinien objąć wszystkie te aspekty. Tymczasem ze względu na niewydolny system resocjalizacji i brak odpowiednich rozwiązań w środowisku lokalnym skazani i ich rodziny są pozbawieni tej możliwości. Następuje jedynie stygmatyzacja byłego więźnia i jego bliskich. Szansę na prowadzenie procesu resocjalizacji w środowisku otwartym daje stosowanie środków półwolnościowych. Włączenie osób do społeczności poprzez działania inkluzyjno-katalaktyczne, oparte na włączaniu i wymianie, prowadzić może do ich usamodzielnienia i wzajemnej wymiany dóbr między skazanym a społeczeństwem. Profesor Andrzej Baładynowicz wniósł szerszy wkład w konferencję, będąc adresatem licznych pytań słuchaczy, a także zostając poproszonym o podsumowanie jej pierwszej części.

Kolejny prelegent, prof. dr hab. Zenon Jasiński z Uniwersytetu Opolskiego, w swoim wystapieniu: Efektywność resocjalizacji w Ochotniczych Hufcach Pracy, ukazał skuteczność resocjalizacji podejmowanej w środowisku, które przeszło udaną transformację i nadal stwarza szansę pracy z młodzieżą niedostosowaną społecznie. Wykładowi towarzyszyła interesująca prezentacja multimedialna, przedstawiona przez dra Edwarda Nycza, ukazująca owoce działalności Ochotniczych Hufców Pracy w przeszłości i w naszych czasach przy zastosowaniu różnych wskaźników ich skuteczności.

Pytanie: Resocjalizować, ale jak? - w społeczeństwie ryzyka i narastajacego konsumeryzmu, stanowiło temat referatu dr hab. Teresy Sołtysiak, prof. UKW, reprezentującej Uniwersytet Kazimierza Wielkiego w Bydgoszczy, która przedstawiła całą panoramę problemów, z jakimi musi liczyć się pedagogika resocjalizacyjna w czasach „kiedy wszystko staje się towarem”. 
Należą do nich: konsumpcyjny niepokój, upadek wartości duchowych i prospołecznych, życie w kręgu potrzeb hedonistycznych, odchodzenie od opiekuńczości w życiu społecznym, marzenia o „przeobrażeniu się w niezwykły towar - towar, o którym się mówi”, posługiwanie się pozorną mądrością, opartą na powierzchownym poznaniu czerpanym z mediów. Świadomość tych problemów jest nieodzownym warunkiem skuteczności działań resocjalizacyjnych.

Przedmiotem wystapienia dr hab. Małgorzaty H. Kowalczyk, prof. UMK, przedstawicielki miejscowej Alma Mater, były: Oddziaływania terapeutyczne i resocjalizacyjne $w$ środowisku otwartym wobec kobiet wykorzystujacych seksualnie dzieci. Autorka referatu scharakteryzowała ten jakże bolesny problem, podając jego cechy konstytutywne i wskaźniki pomocne w ich zdiagnozowaniu, a następnie wskazała na możliwe sposoby przeciwdziałania i terapii, do których należą między innymi: powstrzymanie procesu rewiktimizacji, zmiana mechanizmów obronnych (zależność od sprawcy, zaprzeczanie i wypieranie), zastosowanie opowiadań terapeutycznych, ustalanie jasnych granic, wyznaczanie realistycznych celów, budowanie więzi emocjonalnej i terapia kognitywno-behawioralna.

Następny referat, autorstwa prof. dr hab. Mariusza Jędrzejki, poruszył słuchaczy zarówno gdy chodzi o treść skupioną wokół tematu Zachowania ryzykowne i eksperymenty z substancjami psychoaktywnymi wśród młodzieży - trendy a potrzeby profilaktyki, jak i ze względu na żywy sposób jej prezentacji. Prelegent przedstawił nowe, nieznane dotąd problemy wychowawcze i resocjalizacyjne, które są od niedawna udziałem naszego społeczeństwa. W dobie ,antycypującej socjalizacji” i „kultury presumpcji”, kiedy to rynek techniki reaguje na potrzeby młodych konsumentów, pojawiają się nieznane do tej pory zjawiska, którym trzeba stawić czoło. Zanik fundamentów aksjologicznych, wchłonięcie dzieci i młodzieży przez świat cyberprzestrzeni, w której spędzają nawet $70 \%$ wolnego czasu, pojawienie się nowych uzależnień i politoksykomanii przy jednoczesnej niewydolności systemów wychowawczych i prewencyjnych (pomimo kilkukrotnego wzrostu liczby specjalistów - pedagogów i psychologów w latach 1989-2012) to tylko niektóre z zasygnalizowanych problemów. Prelegent pobudził słuchaczy do refleksji, co zrobić, by zaradzić trudnej sytuacji, która, jak się wydaje, na razie przerasta możliwości obronne społeczeństwa.

Bardzo ciekawe było też ostatnie wystąpienie pierwszej części konferencji. Dr hab. Tomasz Biernat, prof. UMK, reprezentant środowiska naukowego miejscowego Uniwersytetu, zaprezentował Streetworking jako metodę resocjalizacji. Wprowadzając uczestników spotkania w zagadnienie streetworkingu, które w Polsce nie doczekało się jeszcze należnego miejsca w praktyce ani w teorii pedagogicznej, Mówca przedstawił najpierw jego 
odmiany, takie jak: networking czy partyworking, a następnie ukazał istotne walory tak rozumianej metody pracy socjalnej. Należą do nich: poszukiwanie osób w ich naturalnym środowisku, żywa relacja z osobami, wobec których świadczona jest pomoc (funkcja więziotwórcza), autentyczne wsparcie i wzbudzenie poczucia bezpieczeństwa (funkcja pomocowa), inkluzja społeczna, brak dyskryminacji nadzorczej charakterystycznej dla innych form pomocy, rozłożenie oddziaływań w długim przedziale czasowym, bogactwo podejść. Autor przywołał Pejzaż z Miłosiernym Samarytaninem Rembrandta van Rijna jako obraz, który mógłby stanowić symboliczną ilustrację idei streetworkingu.

Po przerwie rozpoczęła się druga część konferencji, którą wypełniły równolegle sesje tematyczne. Moderatorem pierwszej z nich, przebiegającej pod ogólnym hasłem: Praca socjalna i resocjalizacyjna, był dr hab. Tomasz Biernat, prof. UMK. Kolejne wystąpienia odsłaniały różne aspekty i podejścia do resocjalizacji. Dr Edward Nycz z Uniwersytetu Opolskiego zaprezentował referat pod tytułem: Przemiana modelu Ochotniczych Hufców Pracy w kontekście zmian polityczno-społecznych w Polsce. Dr Renata Kowal reprezentująca Wszechnicę Świętokrzyską w Kielcach zapoznała słuchaczy z Profilaktykq w dziataniach Caritas Diecezji Kieleckiej. Próba „uzdrawiania" czlowieka między , chcieć" $i$,,móc” była przedmiotem wystapienia dra Sławomira Chrosta z Uniwersytetu Jana Kochanowskiego w Kielcach. Dr Wojciech Piestrzyński z WSSE w Gdańsku przedstawił referat: Oddziaływania profilaktyczne szkoty w percepcji uczniów, natomiast Wolontariat młodzieży uzależnionej jako otwarta formę resocjalizacji ukazał Krzysztof Zieliński z Uniwersytetu Mikołaja Kopernika w Toruniu. Motywem wspólnym dwóch kolejnych wystapień była problematyka związana z kuratelą sądową: dr Bartłomiej Skowroński z Uniwersytetu Kardynała Stefana Wyszyńskiego poruszył problematykę Wypalenia zawodowego kuratorów sqdowych, zaś Julita Chmielewska i Ewelina Reczuch z Uniwersytetu Warmińsko-Mazurskiego wygłosiły referat Dom zamiast ośrodka, kurator jako przyjaciel - alternatywny sposób resocjalizacji nieletnich.

Sesję: Resocjalizacja z profilaktyka społecznq, prowadził dr Jarosław Horowski z Uniwersytetu Mikołaja Kopernika w Toruniu. Tu większość wystąpień związana była z szeroko pojętą pedagogiką penitencjarną. Pierwszy prelegent - dr Ernest Magda z Uniwersytetu Zielonogórskiego ukazał Różnice w percepcji przestępczości uwarunkowane położeniem życiowym jednost$k i$. Dr Barbara Toroń, reprezentująca tę samą uczelnię, przedstawiła referat: Zachowania przestępcze jako styl życia - poszukiwanie typowości z zastosowaniem metody biograficznej. Opinia spoleczna a codzienna praktyka idei resocjalizacji - to temat wystapienia dr Agnieszki Kowalczyk z Aresztu Śledczego w Lublinie. Mgr Roman Kulma - zastępca Kuratora Okręgowego 
Warszawa-Praga w Warszawie przedstawił zagadnienie: Reformy wymiaru sprawiedliwości w zakresie wykonywania środków probacyjnych. Stosowanie dozoru elektronicznego w Polsce było przedmiotem prezentacji mgr Natalii Daśko i mgra Tomasza Kowalczyka z Uniwersytetu Mikołaja Kopernika w Toruniu. Refleksja Agnieszki Mackiewicz i Sławomira Kasprzaka z Uniwersytetu Zielonogórskiego skupiona była wokół problemu Stygmatyzacji osadzonych. Poza referatami związanymi z problematyką penitencjarną poruszone zostało także zagadnienie: Duszpasterstwa młodzieży z perspektywy resocjalizacyjnej. Na przykladzie przypadku siedemnastoletniego uczestnika duszpasterstwa ministrantów i lektorów, które miałem przyjemność osobiście zaprezentować.

Trzecia grupa tematyczna moderowana przez dr hab. Małgorzatę H. Kowalczyk, prof. UMK, dotyczyła: Społecznej readaptacji osób pozbawionych wolności. Sesję otworzyło wystapienie dr Anny Kieszkowskiej, reprezentującej Państwową Wyższą Szkołę Zawodową w Tarnobrzegu oraz Uniwersytet Jana Kochanowskiego w Kielcach, zatytułowane: Udziat społeczeństwa w powrocie skazanych do środowiska otwartego po odbyciu kary pozbawienia wolności. Następny referat pod tytułem: Model relacyjnej readaptacji skazanych. Przedstawienie nowych dziatań $w$ procesie readaptacji skazanych $w$ środowisku otwartym, zaprezentowała dr Anna Fidelus z Uniwersytetu Kardynała Stefana Wyszyńskiego w Warszawie. Resocjalizację w środowisku zamkniętym a resocjalizację w środowisku otwartym - na przyktadzie nieletnich porównała dr Marta Wilk z Uniwersytetu Jana Kochanowskiego w Kielcach. Ks. dr Piotr Krakowiak z Uniwersytetu Mikołaja Kopernika w Toruniu zapoznał zebranych z Doświadczeniami reintegracji skazanych poprzez wolontariat $w$ ośrodkach paliatywno-hospicyjnych. Reprezentujący Schronisko dla Nieletnich w Gackach mgr Marek Łukasiewicz i mgr Bogusława Łukasiewicz wystapili z referatem: Resocjalizacja nieletnich sprawców czynów karalnych w środowisku otwartym. Potrzeby, możliwości i ograniczenia na przykładzie doświadczeń, praktyki Schroniska dla Nieletnich $w$ województwie świętokrzyskim. Metody readaptacji więźniów powracajacych do życia $w$ środowisku otwartym na gruncie polskim i szkockim porównała mgr Joanna Lizak z Katolickiego Uniwersytetu Lubelskiego, zaś Monika Kaczmarczyk z Uniwersytetu Zielonogórskiego poruszyła problem: Oddziaływania resocjalizacyjnego $w$ środowisku otwartym dla osadzonych w jednostkach penitencjarnych.

Jako uczestnik części plenarnej oraz drugiej sekcji tematycznej konferencji mogę z pełnym przekonaniem stwierdzić, że czas, jaki zagospodarowała uczestnikom spotkania Katedra Teorii Opieki i Wychowania Wydziału Nauk Pedagogicznych Uniwersytetu Mikołaja Kopernika w Toruniu, został dobrze i twórczo wykorzystany. Program konferencji był bardzo bogaty nie 
tylko ze względu na wielość wystąpień i referatów, co było faktem i spowodowało, że nie pozostało zbyt wiele czasu na postawienie pytań i dyskusję, ale przede wszystkim - ze względu na dopełniającą się ich treść, ukazująca całe spektrum zagadnień istotnych dla współczesnej pedagogiki resocjalizacyjnej.

Przewidziany przez organizatorów układ konferencji ułatwiał recepcję przedkładanych treści. Wystąienia - począwszy od ogólnego, programowego referatu prof. Bałandynowicza, poprzez coraz głębiej wnikające w szczegółowe zagadnienia referaty profesorów w części plenarnej i prelegentów sekcji tematycznych - ułożyły się w całość stanowiącą harmonijne, komplementarne, by nie powiedzieć wyczerpujące, ujęcie problematyki resocjalizacyjnej - tak istotnej nie tylko dla teorii, ale przede wszystkim dla praktyki pedagogicznej czasów, w których, jak wykazało to wielu prelegentów, potrzeba rozwijania mądrej pedagogiki resocjalizacyjnej staje się pilna, jak chyba nigdy dotąd.

Zdając relację z toruńskiej konferencji, pozostaje nam jeszcze odnieść się do pytania stanowiącego jej punkt wyjścia - Czy resocjalizacja w środowisku otwartym jest mitem? A może stanowi możliwość, która jest szansą i wyznacza kierunek na przyszłość? Myślę, że każdy, kto wziął udział w konferencji, odpowie twierdząco na drugie z tych pytań. Opowiedzenie się za sensem i skutecznością resocjalizacji w środowisku otwartym nie oznacza uznania, że są one faktem. Wręcz przeciwnie - oznaczają świadomość, jak wiele w tym względzie w Polsce roku 2012 musi się zmienić - z jednej strony konieczne jest budowanie przekonania o szansie, jaką stwarzają mądrze zagospodarowane pod kątem resocjalizacji środowiska o charakterze otwartym - z drugiej owa świadomość powinna mobilizować do dalszych działań w tym zakresie. Pomimo niezbyt optymistycznie wypadającej oceny sytuacji współczesnej polskiej praktyki resocjalizacyjnej, pojawia się nadzieja, że może coś drgnie w tej dziedzinie. 